\title{
Maternal Vasoactive Intestinal Peptide and the Regulation of Embryonic Growth in the Rodent
}

\author{
Joanna M. Hill, ${ }^{\star}$ Susan K. McCune, ${ }^{\star \ddagger}$ Ruben J. Alvero, ${ }^{\star}$ Gordon W. Glazner, ${ }^{\star}$ Karin A. Henins, ${ }^{\star}$ Stephen F. Stanziale, ${ }^{\star}$ \\ Jessica R. Keimowitz, ${ }^{\star}$ and Douglas E. Brenneman* \\ * Section on Developmental and Molecular Pharmacology, Laboratory of Developmental Neurobiology, National Institute \\ of Child Health and Human Development, National Institutes of Health, Bethesda, Maryland 20892; and ${ }^{\ddagger}$ Division of Neonatology, \\ Department of Pediatrics, Johns Hopkins University Hospital, Baltimore, Maryland 21287
}

\begin{abstract}
Vasoactive intestinal peptide (VIP) has been shown to regulate early postimplantation growth in rodents through central nervous system receptors. However, the source of VIP mediating these effects is unknown. Although VIP binding sites are present prenatally, VIP mRNA was not detected in the rat central nervous system before birth and was detected in the periphery only during the last third of pregnancy. In the present study, the embryonic day (E11) rat embryo/trophoblast was shown to have four times the VIP concentration of the E17 fetus and to have VIP receptors in the central nervous system. However, no VIP mRNA was detected in the E11 rat embryo or embryonic membranes by in situ hybridization or reverse transcriptase-PCR. RIA of rat maternal serum revealed a peak in VIP concentration at days E10-E12 of pregnancy, with VIP rising to levels 6-10-fold higher than during the final third of pregnancy. After intravenous administration of radiolabeled VIP to pregnant female mice, undegraded VIP was found in the E10 embryo. These results suggest that maternal tissues may provide neuroendocrine support for embryonic growth through a surge of VIP during early postimplantation development in the rodent. (J. Clin. Invest. 1996. 97:202-208.) Key words: embryo - growth and embryonic development - growth factor $\bullet$ vasoactive intestinal peptide $\bullet$ maternal-fetal exchange
\end{abstract}

\section{Introduction}

Intrauterine growth retardation resulting in small-for-gestational-age babies occurs in $\sim 7 \%$ of all pregnancies (1) and is associated with a high incidence of mortality, morbidity, and neurodevelopmental handicaps (2); however, for as many as $30 \%$ of these births, causal factors are unknown (3). In addition, current knowledge of first trimester phenomena that precede intrauterine growth retardation is especially poor (4).

Vasoactive intestinal peptide (VIP), ${ }^{1}$ a central nervous system (CNS) neurotransmitter and neuromodulator with neu-

Portions of this work have appeared in abstract form (1993. Neurosci. Abstr. 19:1102).

Address correspondence to Joanna M. Hill, Bldg. 49, Room 5A38, LDN/NICHD - NIH, 9000 Rockville Pike, Bethesda, MD 20892. Phone: 301-496-7649; Fax: 301-480-5041.

Received for publication 17 February 1995 and accepted in revised form 28 September 1995.

1. Abbreviations used in this paper: $\mathrm{CNS}$, central nervous system; E, embryonic day; $\alpha$-MSH, $\alpha$-melanocyte-stimulating hormone; RT, reverse transcriptase; VIP, vasoactive intestinal peptide.

The Journal of Clinical Investigation,

Volume 97, Number 1, January 1996, 202-208 rotrophic properties (5-10), has recently been shown to regulate growth in rodents during the early postimplantation period $(11,12)$. This midgestational period, embryonic days (E) 9-11 in the mouse, follows neural tube closure and the beginning of neurogenesis and is characterized by critical developmental events including embryogenesis, organogenesis, and the transfer from yolk sac to placental exchange. In the cultured whole mouse embryo at E9.5, VIP dramatically accelerated embryonic growth (11). A 4-h treatment with VIP resulted in a doubling of the DNA content and stimulated mitosis as measured by concentration-dependent increases in the number of cells in S-phase (up to a sixfold increase). Blocking VIP functions during this period, by treating pregnant mice with a VIP antagonist from E9.5 to E11.5, produced growth retardation accompanied by microcephaly (12). Importantly, since blockage of VIP after E11.5 in the mouse did not retard growth (12), the regulatory effects of VIP on growth are apparently limited to a brief early postimplantation period in the rodent. In human pregnancy, the postimplantation period from approximately days 22 to 32 corresponds to the midgestational period of the rodent and is the time span in which similar developmental events occur in the human embryo (13).

The growth-regulating actions of VIP occurred through VIP binding sites which, at midgestation, were restricted to CNS structures. VIP treatment down-regulated VIP binding sites (11), and treatment with a VIP antagonist up-regulated these sites (12). VIP receptors have been shown to be abundant throughout the development of the nervous system and demonstrated dynamic distribution patterns, exhibiting changes in receptor types and numbers relative to changing ontogenic events (14). However, the mRNA for VIP was not apparent in the CNS at any time before birth; in other sites, such as the sphenopalatine ganglion and intestine, VIP mRNA was observed only during the last third of pregnancy in the rat (14).

The apparent absence of VIP synthesis in the embryo during the early postimplantation period, when growth is under VIP regulation, suggests that VIP from an extraembryonic source reaches the embryonic nervous system to regulate the growth and development of the embryo. The purpose of the present work is to examine extraembryonic tissues and maternal blood as potential sources of VIP.

\section{Methods}

Measurement of VIP in the embryo/fetus during mid-and late gestation. To determine if VIP was present in the rat embryo during the early postimplantation period (midgestation) and to compare the concentration at this time period with the last third of gestation, VIP was measured in E11 embryos including extraembryonic fluids and membranes and compared with the VIP concentration in fetuses including membranes and fluids at E17. To avoid the addition of any maternal decidua, the embryo trophectoderm in the region of implantation was excluded in the E11 embryo. Rats were chosen for this 
study due to the large quantities of tissues and fluids available for measurement. Mouse and rat exhibit similar developmental rates; however, the developmental events occurring in the mouse embryo during E9 to E11 occur from E10 to E12 in the rat $(15,16)$. Ten pregnant rats were guillotined on day E11 of gestation and seven on E17 of gestation and the embryos and fetuses were dissected from the uterus, weighed, and homogenized in $1 \mathrm{ml}$ of $0.1 \mathrm{~N} \mathrm{HCl}$. The E17 placentae were homogenized and analyzed separately. The E11 embryos were pooled in groups of three, but E17 fetuses were homogenized separately. The homogenates were immediately frozen on dry ice and stored at $-80^{\circ} \mathrm{C}$. To extract VIP from the tissues for RIA measurement, homogenates were thawed and transferred to glass tubes. The volume was brought up to $3 \mathrm{ml}$ with $0.1 \mathrm{~N} \mathrm{HCl}$ and the contents mixed thoroughly. Tubes were placed in a heating block at $100^{\circ} \mathrm{C}$ for $10 \mathrm{~min}$. After cooling on ice, the samples were thoroughly mixed, and 1-ml samples from each tube were spun at $10,000 \mathrm{~g}$ for $30 \mathrm{~min}$. $500 \mu \mathrm{l}$ of the supernatant was transferred to polystyrene tubes and diluted 1:1 with deionized water. The tubes were evaporated to dryness in a vacuum concentrator. The residue was dissolved in RIA buffer and VIP measured with an RIA kit from Peninsula Laboratories Inc. (Belmont, CA) with an $\mathrm{IC}_{50}$ of $14.9 \mathrm{pg} / 100-\mu \mathrm{l}$ sample. Data were analyzed by Student's $t$ test using Statview software from Abacus Concepts Inc. (Berkeley, CA).

In vitro autoradiography with ${ }^{125}$ I-VIP and in situ hybridization histochemistry. Binding sites for VIP were examined on six embryos, including extraembryonic tissues on each of days E10-E13 of gestation. Three placentae were examined for each day throughout the remainder of pregnancy for the distribution of VIP binding sites. From E10 to E13, embryos and all embryonic membranes were dissected from the uterus and immediately frozen on dry ice. From E13 to E21, three placentae per age were dissected out separately and immediately frozen on dry ice. Tissues were sectioned at $20 \mu \mathrm{m}$ on a cryostat, dried, and frozen at $-80^{\circ} \mathrm{C}$ until use. Alternate sections were used for in situ hybridization histochemistry.

To localize binding sites for VIP, in vitro autoradiography with ${ }^{125}$ I-VIP was performed as described previously $(14,17)$. Briefly, slides were brought to room temperature and preincubated for 30 min in $10 \mathrm{mM}$ Hepes with $130 \mathrm{mM} \mathrm{NaCl}, 4.7 \mathrm{mM} \mathrm{KCl}, 5 \mathrm{mM} \mathrm{MgCl}_{2}, 5$ $\mathrm{mM} \mathrm{MnCl}, 1 \mathrm{mM}$ EDTA and $1 \%$ BSA with $\mathrm{pH}$ adjusted to 7.4 with $\mathrm{NaOH}$, followed by a 1-h incubation in the same buffer at room temperature with $1 \mathrm{mg} / \mathrm{ml}$ bacitracin and $50 \mathrm{pM}^{125}$ I-labeled VIP (Amersham Corp., Arlington Heights, IL) with and without $1 \mu \mathrm{M}$ VIP (Peninsula Laboratories Inc.) to determine specific binding, or $10 \mu \mathrm{M}$ of the stable GTP analogue guanylyl imidodiphosphate to differentiate GTP-sensitive from GTP-insensitive binding sites (17). After incubation, the slides were transferred through three 1-min rinses of cold PBS, $\mathrm{pH} 7.4$, and rapidly dried under a stream of cool air. Sections were placed in a cassette with Hyperfilm- ${ }^{3} \mathrm{H}$ (Amersham Corp.) for $4 \mathrm{~d}$. The autoradiograms were developed in Kodak D-19 (Eastman Kodak Co., Rochester, NY). The density of labeled VIP binding was analyzed by digitizing the film images using a Macintosh-II-based image analysis system (IMAGE; Wayne Rasband, Research Services Branch, National Institute for Mental Health, Bethesda, MD). Light transmittance measures were determined from at least four embryo/ trophoblasts, and specific binding was determined by subtracting the transmittance of tissue incubated with $1-\mu \mathrm{M}$ unlabeled VIP (nonspecific binding) from the total transmittance. Data were analyzed by ANOVA using Statview by Abacus Concepts Inc.

In situ hybridization histochemistry was performed on E10-E13 embryos and extraembryonic membranes and on placentae from E13 to the end of gestation. The tissues were prepared as above and the sections used were adjacent to those used for in vitro autoradiography. The preparation of probes and in situ hybridization histochemistry was performed as previously described (14). In brief, oligonucleotide probes were derived from published rat cDNA sequences (18). They were end-labeled individually using terminal deoxynucleotidyl transferase from Bethesda Research Laboratories (Bethesda, MD) and $\left[{ }^{35} \mathrm{~S}\right]$ deoxyadenosine $5^{\prime}$-(alpha-thio)triphosphate purchased from
DuPont New England Nuclear (Boston, MA) as previously described (19). Slides were thawed, fixed, and hybridized as previously described (14). After hybridization and subsequent washes (14), the slides were placed against $\beta$ Max film (Amersham Corp.) for an exposure of 11-17 d at room temperature. Film was developed in Kodak D19.

Reverse transcriptase (RT)-PCR. RT-PCR, to detect VIP mRNA, was performed on E11 rat embryos, extraembryonic membranes, and the placentae from E15, E16, E17, and E18. Adult rat cortex was used as a positive control tissue. Tissues were dissected from four embryos. To avoid the addition of maternal decidua, care was taken to exclude the embryonic trophectoderm in the region of implantation. The embryos and membranes were washed separately three times in PBS, immersed in $1 \mathrm{ml}$ Stat-60 from Tel-Test "B" (Friendswood, TX), and dissolved by sonication for isolation of total RNA by the acid guanidinium/phenol chloroform method (20). RNA samples were reverse transcribed, and a portion of the cDNA product was semiquantitated using the PCR (21). Cyclophilin was used as a standard to determine the amount of cDNA in each reaction. DNA sequences for VIP (M86835) and cyclophilin (M19533) were obtained from the GenBank. The primer sets were designed using Oligo software from $\mathrm{Na}-$ tional Biosciences, Inc. (Plymouth, MN) and were synthesized by Cruachem Inc. (Dulles, VA). The following primer sequences were used (22, 23): (a) VIP/5: 5' -ATGCCTTAGCGGAGAATGAC-3'; (b) VIP/ 3: 5'-TTCTAAGGCGGGTGTAGTTATC-3'; (c) cyclophilin/5: 5'GGTCAACCCCACCGTGTTCT-3'; (d) cyclophilin/3: 5'-TGCCATCCAGCCACTCAGTCT-3'. As previously described (24), 20\% of each RNA sample was reverse transcribed with random hexamer primers and $8 \mu \mathrm{l}$ of the cDNA products were subjected to PCR amplification with the VIP and cyclophilin primers. Reactions were carried out in Taq DNA polymerase buffer $(50 \mathrm{mM} \mathrm{KCl}, 10 \mathrm{mM}$ Tris- $\mathrm{HCl}, \mathrm{pH}$ 8.3) containing $200 \mu \mathrm{M}$ dNTP's, $2 \mathrm{mM} \mathrm{MgCl}_{2}, 0.5 \mu \mathrm{M}$ of each primer, and 2.5 U Taq DNA polymerase purchased from Boehringer Mannheim Biochemicals (Indianapolis, IN). To prevent evaporation, samples were overlaid with $50 \mu \mathrm{l}$ mineral oil. PCR amplification was carried out in a thermal controller (N801; Perkin-Elmer Corp., Norwalk, CT). The amplification program consisted of a denaturing step at $95^{\circ} \mathrm{C}$ for $1 \mathrm{~min}$, an annealing step at $60^{\circ} \mathrm{C}$ for $1 \mathrm{~min}$, and a synthesis step at $72^{\circ} \mathrm{C}$ for $1 \mathrm{~min}$. PCR reactions were performed for each primer pair, and 5- $\mu 1$ aliquots were removed every 4 cycles from 15 to 35 cycles to determine the kinetics of amplification. Products were separated through a $4-20 \%$ acrylamide minigel from Novex (San Diego, CA) and stained in $1 \mu \mathrm{g} / \mathrm{ml}$ ethidium bromide from GIBCO BRL (Gaithersburg, MD). Gel Marker-1 from Research Genetics (Huntsville, $\mathrm{AL}$ ) was used as an electrophoresis marker to determine product size.

Measurement of VIP, somatostatin, and $\alpha$-melanocyte-stimulating hormone in maternal serum. Beginning at $\mathrm{E} 9$, the maternal blood was examined daily for the presence of VIP. The concentrations of somatostatin and $\alpha$-melanocyte-stimulating hormone $(\alpha-\mathrm{MSH})$ were also measured as reference peptides to control for variation in sample preparation and testing. Blood was collected from a minimum of nine Sprague-Dawley rats on each day of pregnancy from E9 to E21 (at least three animals per age in each of three separate experiments). The rats were guillotined, and the blood was collected in a beaker containing $50 \mu \mathrm{l}$ of a $15 \%$ solution of EDTA for each $10 \mathrm{ml}$ blood. Immediately upon collection, 3,500 KIU of aprotinin from Boehringer Mannheim Biochemicals was added for each $10 \mathrm{ml}$ of blood. The blood was spun at $1,600 \mathrm{~g}$ for $10 \mathrm{~min}$. The supernatant was frozen on dry ice, and kept at $-80^{\circ} \mathrm{C}$ until use.

The RIA for VIP, somatostatin, and $\alpha$-MSH measures were performed by Hazelton Washington, Vienna, VA, with the use of RIA kits from IncStar Corp. (Stillwater, MN) Data were analyzed by oneway ANOVA using Statview.

Determination of transport of VIP from maternal blood to the embryo and stability of VIP in rat serum. To determine if intact VIP could be transported from mother to embryo during the critical period for VIP regulation of growth two E10 pregnant mice were injected in the uterine vasculature with $10-20 \mu \mathrm{Ci}$ of ${ }^{125} \mathrm{I}-\mathrm{VIP}$ from Amersham Corp., and after $15 \mathrm{~min}$ the mice were guillotined and the 
embryos removed. The embryos plus extraembryonic membranes (excluding the embryonic trophectoderm in the region of implantation) were dissected and pooled, three to a sample, and homogenized in $300 \mu \mathrm{l}$ of PBS to which SDS was added to make a $2 \%$ solution. The homogenized material was spun at 10,000 rpm for $10 \mathrm{~min}$, and the supernatant was removed. Samples of the embryo supernatant were applied to $16 \%$ acrylamide SDS electrophoresis gels from Novex along with stock ${ }^{125}$ I-VIP which were run according to the manufacturer's instructions. The gels were then dried, wrapped in plastic film, and exposed to Hyperfilm- ${ }^{3} \mathrm{H}$ for $10 \mathrm{~d}$.

To evaluate the stability of ${ }^{125}$ I-VIP exposed to serum for $15 \mathrm{~min}$, serum from two E11 day pregnant rats and two adult male rats was collected as above without the addition of EDTA and aprotonin. 50 $\mu \mathrm{l}$ of each sample were incubated with $15,000 \mathrm{cpm}$ of ${ }^{125} \mathrm{I}$-VIP in $40 \mu \mathrm{l}$ PBS for $15 \mathrm{~min}$ at $37^{\circ} \mathrm{C}$. Samples of the E11 serum, both before and after incubation, and the male serum were applied to SDS electrophoresis gels and treated as above.

As an estimate of the amount of intact VIP reaching embryonic and fetal tissues from maternal blood, size-separation chromatography was performed on tissues from eight pregnant rats, four at E10 and four at E17, injected in the femoral or uterine vasculature with $10-20 \mu \mathrm{Ci}$ of ${ }^{125} \mathrm{I}-\mathrm{VIP}$. After $15 \mathrm{~min}$ to $1 \mathrm{~h}$, the rats were guillotined and the embryo/fetuses removed. E10 embryos plus extraembryonic membranes (excluding the embryonic trophectoderm in the region of implantation) were pooled, three to a sample, and homogenized in $300 \mu \mathrm{l}$ of $0.1 \mathrm{~N} \mathrm{HCl}$. The E17 fetuses were gently perfused through the heart with $200 \mu \mathrm{l}$ of PBS and the brains removed. The brains from the fetuses were pooled, three to a sample, and homogenized in 300 $\mu 1$ of $0.1 \mathrm{~N} \mathrm{HCl}$. Placentas from E17 fetuses were also homogenized. The homogenized material was spun at $10,000 \mathrm{rpm}$ for $10 \mathrm{~min}$, and the supernatant was removed. Samples of the stock solution of ${ }^{125} \mathrm{I}$ VIP and the tissue supernatants were applied to a fast performance liquid chromatography size-separation column, the fractions collected, and the radioactivity in each fraction counted. Some E17 fetuses, from mothers that had been injected with ${ }^{125} \mathrm{I}$-VIP, were frozen, sectioned at $20 \mu \mathrm{m}$, dehydrated overnight at $0^{\circ} \mathrm{C}$, and exposed to $\mathrm{Hy}-$ perfilm $-{ }^{3} \mathrm{H}$ in a cassette for $15 \mathrm{~d}$. Autoradiographic films were developed in D19 for 4 min.

\section{Results}

Comparison of VIP in embryo/trophoblasts at midgestation and fetuses at late gestation. The VIP content (mean \pm SEM) of the rat E11 embryo (including fluids and embryonic mem- branes) was $0.91 \pm 0.2 \mathrm{pg} \mathrm{VIP} / \mathrm{mg}$ wet wt ( 33 embryos from 10 mothers) and was significantly greater than the VIP content of the E17 fetuses and their membranes and fluids which was $0.23 \pm 0.02 \mathrm{pg} \mathrm{VIP} / \mathrm{mg}$ wet wt (20 fetuses from 7 mothers) (Student's $t$ test, $P<0.0001)$. The VIP concentration of the E17 placenta was $0.24 \pm 0.02 \mathrm{pg} \mathrm{VIP} / \mathrm{mg}$ wet wt ( 7 placentae from 3 mothers).

In vitro autoradiography. Due to the small size of E10 embryos ( 3 and 8 somites) an accurate assessment of VIP binding could not be made from autoradiographs. In the older embryos, ${ }^{125}$ I-VIP bound to receptors throughout the brain and spinal cord (Fig. $1 A$ ), and the addition of $1 \mu \mathrm{M}$ unlabeled VIP to the incubation medium reduced ${ }^{125}$ I-VIP binding to almost background levels (Fig. $1 \mathrm{~B}$ ). In the E11 and E12 embryos, moderately dense specific VIP binding was seen only in the brain and spinal cord. This binding was GTP insensitive as none was displaced with GTP. In the E13 embryo (Fig. $1 A$ ), VIP binding sites were also limited to the brain and spinal cord; however, in the spinal cord, binding sites were approximately triple the density seen at E11. Within the possible optical density range of $0-255$, the E13 spinal cord had an OD of $99 \pm 4.2$ (mean \pm SEM) compared with a density of $38 \pm 4.5$ for E11 spinal cord, ANOVA, $P<0.001$, and reached the high levels achieved in the spinal cord of E14 rat embryos (14). About $50 \%$ of the binding in the E13 spinal cord was displaced with GTP. Specific VIP binding was not seen in the placenta.

In situ hybridization histochemistry and RT-PCR. In situ hybridization histochemistry did not reveal mRNA for VIP in the embryo, embryonic membranes, or the placenta at any stage of pregnancy examined. However, abundant mRNA for alpha adrenergic receptor subtypes (25) was apparent on embryo sections adjacent to those previously used to localize the mRNA for VIP during development (14), sustaining the integrity of the tissue and methodologies. In addition, in adult rat brain sections processed as positive controls, the oligonucleotide localized abundant VIP mRNA as previously described (14). RT-PCR did not reveal mRNA for VIP in either E11 embryo or the extraembryonic membranes examined with 35 cycles amplification. This method detected mRNA for VIP in the adult rat cortex at 25 cycles and in the E15-E18 placenta at 30 cycles.

$V I P$, somatostatin, and $\alpha-M S H$ in maternal serum. During
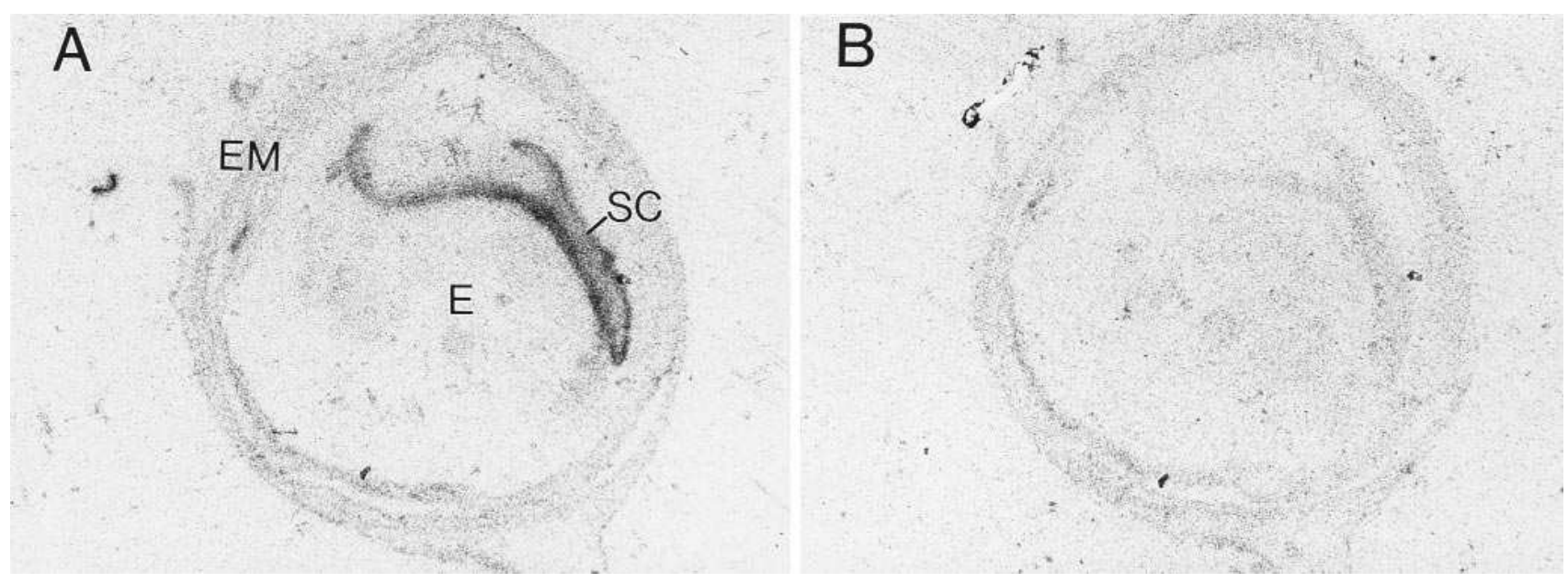

Figure 1. Autoradiograph of ${ }^{125} \mathrm{I}$-VIP binding in an E13 rat embryo within extraembryonic membranes. $(A)$. Total ${ }^{125} \mathrm{I}$-VIP binding. $(B){ }^{125} \mathrm{I}-\mathrm{VIP}$ binding in the presence of $1 \mu \mathrm{M}$ unlabeled VIP. Specific VIP binding is limited to the brain and spinal cord. Sagittal view, $\times 10$. Tissue slices were incubated under the conditions described in Methods. $E$, embryo; $E M$, extraembryonic membranes; $S C$, spinal cord. 


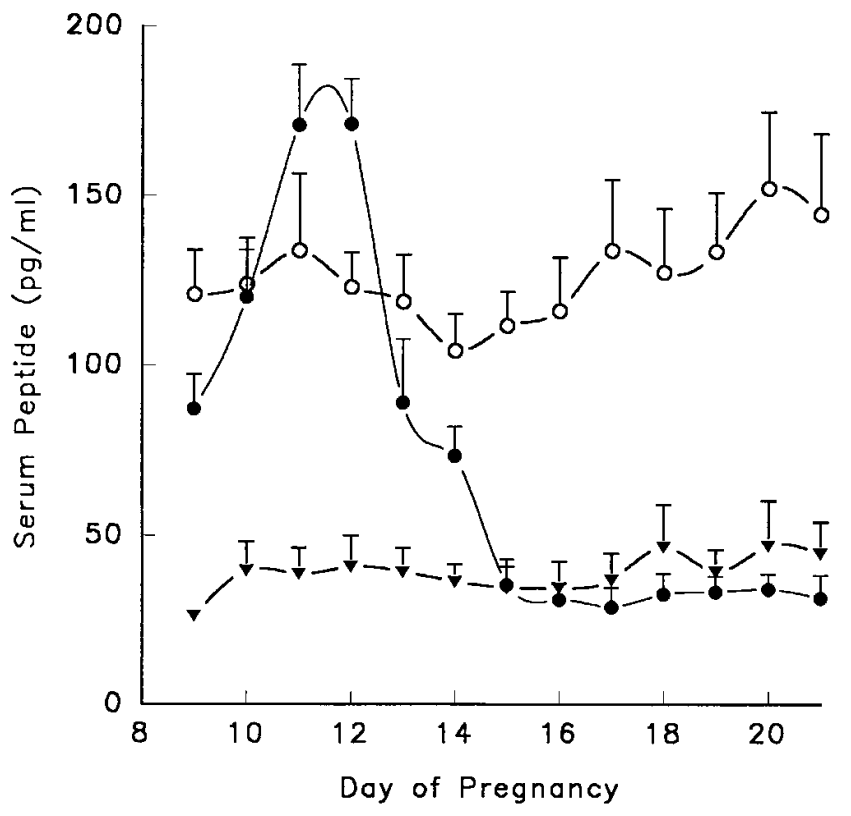

Figure 2. Mean concentration in $\mathrm{pg} / \mathrm{ml} \pm$ SEM of VIP, $\alpha-\mathrm{MSH}$, and somatostatin in maternal rat serum from days 9 to 21 of pregnancy as determined by RIA. Data was obtained from three separate experiments. The concentration of VIP in serum on days 11 and 12 was significantly different from other days of pregnancy, $P<0.05$, ANOVA. ○, VIP; $\bigcirc, \alpha-\mathrm{MSH} ; \mathbf{\nabla}$, somatostatin.

midgestation, maternal serum exhibited a peak in VIP concentration 6-10 times greater than levels seen later during pregnancy (Fig. 2). Beginning at $\sim 90 \mathrm{pg} / \mathrm{ml}$ at day 9 , VIP levels rose to a peak of $170 \mathrm{pg} / \mathrm{ml}$ by day 11 , which was maintained for $2 \mathrm{~d}$ then gradually decreased until day 15 . From day 15 to the end of pregnancy, a lower level of $\sim 30 \mathrm{pg} / \mathrm{ml}$ was maintained.

The concentrations of $\alpha-\mathrm{MSH}$ and somatostatin, which were relatively constant from day 9 until the end of pregnancy (Fig. 2), suggested that the serum collection and handling procedures were consistent throughout the study. $\alpha$-MSH levels were $\sim 125 \mathrm{pg} / \mathrm{ml}$ throughout most of pregnancy with a rise to $\sim 150 \mathrm{pg} / \mathrm{ml}$ beginning at about day 17 and lasting until birth. Somatostatin levels remained at $\sim 40 \mathrm{pg} / \mathrm{ml}$ throughout pregnancy.

Transport of VIP from maternal blood to the embryo and stability of VIP in rat serum. SDS gel electrophoresis of E10 embryo/trophoblast supernatant from pregnant mice receiving ${ }^{125} \mathrm{I}$-VIP in the uterine vasculature $15 \mathrm{~min}$ before killing, revealed that radiolabeled material reached the embryo (Fig. 3, lane $E$ ). Since both the stock radiolabeled VIP (lanes $D$ and $F$ ) and the radiolabeled material from the supernatant of E10 embryos (lane $E$ ) migrated to $\sim 3.3 \mathrm{kD}$, the molecular mass of VIP, ${ }^{125}$ I-VIP apparently underwent little degradation in its passage to the embryo. However, a slight smear under the 3.3-kD band of the E10 embryo suggests some degradation took place. Most of the radiolabeled material from ${ }^{125}$ I-VIP incubated in serum from both E11 pregnant rats (lane $B$ ) and adult male rats (lane $C$ ) also migrated to $3.3 \mathrm{kD}$, with small amounts appearing as a smear under the major band. Little degradation of ${ }^{125}$ I-VIP was apparent in nonincubated E11 serum (lane $A$ ). In size-separation chromatography of homogenates of whole E10 embryo (including embryonic fluids and

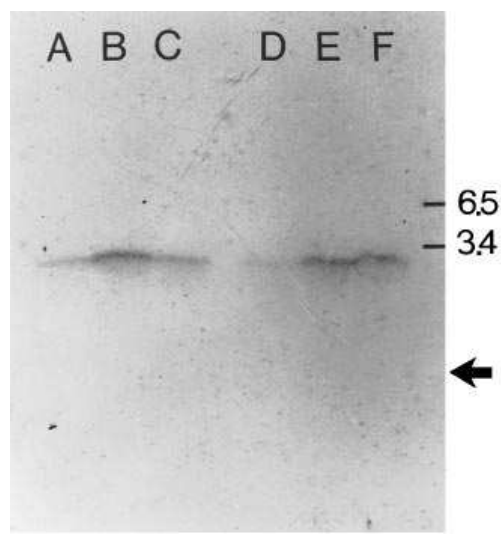

Figure 3. SDS gel electrophoresis of ${ }^{125}$ I-VIP after 15-min incubation at $37^{\circ} \mathrm{C}$ in serum or recovered from E10 mouse embryos the mothers of which received ${ }^{125}$ I-VIP via intrauterine vasculature injection 15 min before dissection. Tissue preparation and gel electrophoresis were performed as described in Methods. $(A)^{125}$ I-VIP in serum from pregnant rats at E11 of gestation before incubation; $(B){ }^{125}$ I-VIP in E11 pregnant rat serum after incubation; $(C){ }^{125} \mathrm{I}-\mathrm{VIP}$ in serum from adult male rat; $(D)$ and $(F){ }^{125}$ I-VIP stock solution before incubation or injection; $(E)^{125}$ I-VIP recovered from E10 mouse embryos. Molecular mass markers: 6.5 and $3.4 \mathrm{kD}$. Arrow indicates dye front.

membranes) from mothers receiving ${ }^{125}$ I-VIP in the uterine vasculature $15 \mathrm{~min}$ before killing, $22 \%$ of the labeled material coeluted with intact VIP in fractions 36-40 (Fig. 4). The remaining label was associated with smaller fragments. In homogenates of perfused brain tissue from E17 rat fetuses, the mothers of which were injected into the uterine vasculature with radiolabeled VIP 15 min before dissection, $28 \%$ of the radiolabeled material in brain coeluted with intact VIP. In placentae, $46 \%$ of the radiolabeled material coeluted with VIP. Autoradiography of sections taken from fetuses, the mothers of which were injected into the femoral vasculature with ${ }^{125}$ I-VIP, revealed that radiolabeled material reached the fetal brain (Fig. 5). In the brain, a small amount of radiolabeled material was localized to the superficial layers of the cortex and the brain tissue surrounding the lateral ventricle. Radiolabeled material was also dense in the placenta and eye.

\section{Discussion}

The results of the current study suggest that the maternal tissues are a source of VIP acting on VIP binding sites in the embryonic nervous system to regulate growth during the early postimplantation period of embryogenesis. The concentration of VIP in the E11 embryo was found to be four times the concentration at E17, despite the fact that at this earlier age, VIP mRNA was not revealed by either in situ hybridization or RTPCR. However, the maternal blood exhibited a peak in VIP concentration which coincided with this critical midgestational period during which VIP has been shown to regulate embryonic growth $(11,12)$. A mechanism for the transfer of VIP from maternal circulation to the early postimplantation embryo exists since labeled VIP introduced into the maternal vasculature was found in the embryo and, 15 min after introduction, much of this material remained undegraded. Thus, the surge of VIP in the rat maternal circulation during this critical period could result in the transfer of VIP to the embryo. Although the source of serum VIP is not yet known, the peak in 


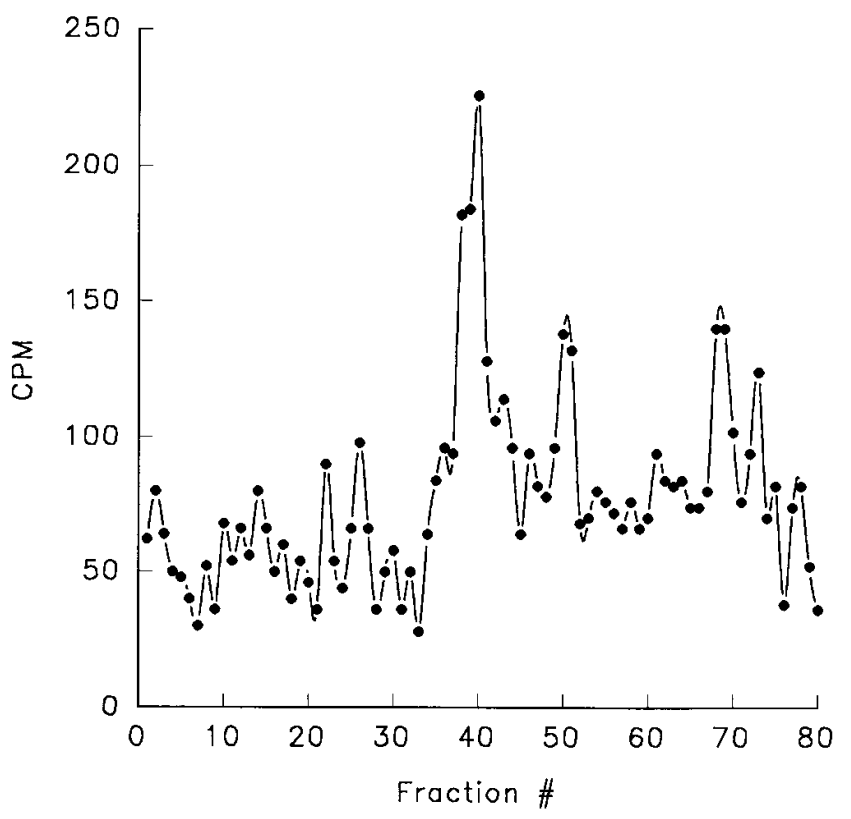

Figure 4. Radiolabeled material (CPM) recovered from size-separation chromatography fractions from E10 embryos, the mothers of which received $10 \mu \mathrm{Ci}$ of ${ }^{125} \mathrm{I}-\mathrm{VIP}$ injected into the uterine vasculature 15 min before killing. Stock ${ }^{125}$ I-VIP eluted into fractions $36-40$ and the material appearing in these fractions is considered to be undegraded VIP. The labeled material occurring in fractions 41-80 represents degradation products.

VIP concentration in maternal serum may reflect increased synthesis in maternal tissues and/or decreased degradation in the serum.

We previously reported that VIP binding sites were abundant during the early postimplantation period in mouse embryos and limited to the CNS $(11,12)$. We show here that the early postimplantation embryonic rat also exhibited VIP binding sites which were restricted to the CNS. In addition, the current study shows that the type of VIP binding site undergoes a change after this critical period. At E11 and E12, during the peak of VIP in maternal serum, VIP binding sites throughout the CNS were moderately abundant, but were only of the GTP-insensitive type. By day 13, coinciding with a fall in maternal serum VIP, VIP binding sites tripled in the spinal cord and were 50\% GTP insensitive and 50\% GTP sensitive. Previous studies have linked the GTP-insensitive VIP binding site in the midgestational embryo CNS with the promotion of growth through VIP-stimulated mitogenesis of the neuroepithelium (11). The current data are consistent with this concept since the GTP-insensitive binding site is the first to appear and is present in the CNS during the time when VIP is known to stimulate CNS growth and development. The increase in VIP binding sites may also indicate a role for VIP in neuronal migration, differentiation, and/or axogenesis, for these events are known to begin in the ventral horn motor neurons of the cervical region of the rat spinal cord on E12 (26).

The fall of VIP in maternal serum is also closely followed by the appearance of VIP mRNA in fetal peripheral tissues $(14,27)$, including the peripheral nervous system where VIP is seen to peak in the stellate ganglia at E14.5 (28), and significant amounts of VIP were also detected in the superior cervical ganglia (10). The VIP synthesized by peripheral fetal tis-

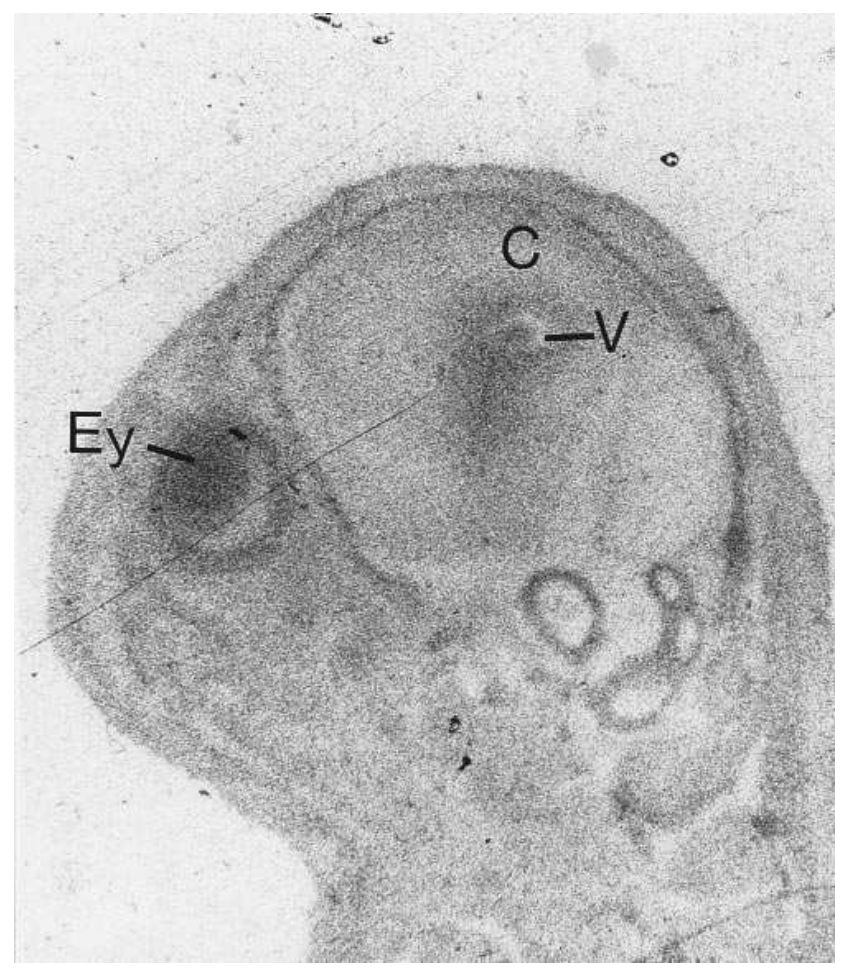

Figure 5. Autoradiography of the head of an E17 rat fetus the mother of which received $10 \mu \mathrm{Ci}^{125}$ I-VIP into the femoral vasculature $1 \mathrm{~h}$ before killing. Labeled material reached the brain where it can be seen in the cortex and surrounding the ventricle. The eye exhibits dense accumulation of radiolabeled material. Sagittal view, $\times 5$. C, cortex; $E y$, eye; $V$ lateral ventricle.

sues during the last third of pregnancy may provide a source of VIP to act on the abundant VIP binding sites seen throughout the CNS during this time (14). Although the levels of VIP mRNA were undetectable in the E13 to E21 placenta by in situ hybridization techniques, RT-PCR provided evidence that the mRNA was present in the E15 to E18 placenta suggesting that, at this age, the placenta may also provide VIP. Whether the more sensitive methods of RT-PCR will reveal low levels of VIP mRNA in preplacental tissues earlier in gestation is not yet known; however, in situ hybridization histochemistry did not reveal VIP mRNA in the E11 embryonic trophectoderm or maternal decidua at the site of implantation.

The recognized receptor for VIP is linked to adenylate cyclase, and GTP sensitivity is characteristic of these receptors (29). The second messenger system through which the GTPinsensitive binding sites operate is unclear; however, in astrocyte cultures a high affinity non-cAMP-linked VIP binding site has been identified which is associated with glial mitosis, secretion, and the neurotrophic actions of VIP (5-8). In addition, recent studies have shown that subnanomolar concentrations of VIP stimulate the accumulation of intracellular calcium, increase inositol phosphates in astrocyte cultures (30), and produce translocation of selected protein kinase $\mathrm{C}$ isozymes (31). Although it is not known if the growth-regulatory functions of VIP in the CNS are synonymous with the promotion of neuronal survival, current data suggest that these activities may occur through high affinity VIP binding sites linked to a non-cAMP, calcium-generating second messenger system. It is of additional interest that the peak concentration 
of VIP in the maternal serum of $170 \mathrm{pg} / \mathrm{ml}$ is within the $30-50$ pM range (99-165 pg/ml) which is the $K_{\mathrm{d}}$ reported for the high affinity VIP receptor in astrocytes (32).

The VIP concentration of $0.91 \mathrm{pg} / \mathrm{mg}$ in the E11 embryo is higher than the $170 \mathrm{pg} / \mathrm{ml}(0.17 \mathrm{pg} / \mathrm{mg})$ of VIP found in maternal serum at this time suggesting that there is a concentrating effect in the embryo and/or the uterine circulation. The measure we obtained from the maternal serum was from blood collected from the entire circulatory system; however, higher concentrations of VIP may be reached within the uterine vasculature. The concentration of VIP in the human umbilical vasculature has been reported to be $\sim 2.5$ times greater than in maternal venous blood (33), suggesting that VIP is selectively concentrated in the uterine circulation.

Past work has suggested that VIP concentration is held within a narrow range during midgestation (12). Cotreatment of pregnant mice with intraperitoneal injections of $0.2-2.0 \mu \mathrm{g} / \mathrm{g}$ VIP and a VIP antagonist prevented the antagonist-induced growth retardation; however, this concentration of VIP was lethal to embryos when pregnant mice received it alone (12). There was no apparent damage to the mothers at any dose. These data suggest that the in vivo levels of VIP optimal for the promotion of growth are regulated within a relatively narrow range of concentrations and that potential defects in CNS growth could be associated with disregulation of this peptide during development.

An alternate explanation of the observation that embryonic growth is regulated by VIP in the absence of VIP synthesis in the embryo is that this occurs through a related peptide such as peptide histidine isoleucine, secretin or pituitary adenylate cyclase-activating polypeptide (PACAP) acting on VIP receptors. However, peptide histidine isoleucine has not been detected in the CNS prenatally (14), and neither secretin (11) nor PACAP (Hill, J. M., unpublished data) stimulated growth of cultured mouse embryos. Additionally, PACAP was not only unable to prevent the impairment of growth produced by the blockage of VIP in midgestation but also had an effect on cell number opposite to that of VIP (12).

Although the maternal circulation provides nutrients for the developing young, maternal neurotransmitters and hormones have not commonly been thought to undergo maternalto-fetal transfer. Exceptions to this are the rather free passage of steroid hormones and the slower transfer of the thyroid hormones (34). Thyroid hormone is necessary for CNS development and maternal serum provides a source of thyroid hormone during in utero development $(35,36)$. Recent evidence has indicated that at E11 maternal insulin is available to the rat embryo (37). In addition, several cytokines are thought to play a role in early gestation $(38,39)$. Among these, granulocyte colony-stimulating factor has been shown to undergo transplacental maternal-to-fetal transport and play a role in fetal bone marrow and spleen myelopoiesis (40). These recent findings indicate that several maternal factors may be involved in the regulation of the complex sequence of events resulting in coordinated prenatal development.

Although other growth-promoting substances could possibly be acting at VIP binding sites regulating embryonic growth, current information would suggest that the maternal tissues are an important source of VIP for the developing embryo. Additionally, the coincidence of a peak in maternal circulatory VIP occurring exactly within the critical period for VIP regulation of embryonic growth is perhaps the most salient indicator that maternal VIP contributes to the regulation of embryogenesis.

\section{Acknowledgments}

The authors gratefully acknowledge the excellent technical assistance of Daniel Abebe.

\section{References}

1. Wegman, M. E. 1992. Annual summary of vital statistics. 1991. Pediatrics. 90:835-845.

2. McCormick, M. C. 1985 . The contribution of low birth weight to infant mortality and childhood morbidity. N. Engl. J. Med. 312:82-90.

3. Leger, J., and P. Czernichow. 1994. Retardation of intrauterine growth. Prognosis and therapeutic perspectives (editorial). Presse Med. 23:969-971.

4. Peeters, L. L. 1994. The effect of early maternal maladaptation on fetal growth. J. Perinat. Med. 22(Suppl. 1):9-17.

5. Brenneman, D. E., T. Nicol, D. Warren, and L. M. Bowers. 1990. Vasoactive intestinal peptide: a neurotrophic releasing agent and an astroglial mitogen. J. Neurosci. Res. 25:386-394.

6. Brenneman, D. E., L. E. Eiden, and R. E. Siegel. 1985. Neurotrophic action of VIP on spinal cord cultures. Peptides (Tarryt.). 6(Suppl.2):35-39.

7. Brenneman, D. E., and L. E. Eiden. 1986. Vasoactive intestinal peptide and electrical activity influence neuronal survival. Proc. Natl. Acad. Sci. USA. 83:1159-1162.

8. Brenneman, D. E., E. A. Neale, G. A. Foster, S. W. d'Autremont, and G. L. Westbrook. 1987. Nonneuronal cells mediate neurotrophic action of vasoactive intestinal peptide. J. Cell Biol. 104:1603-1610.

9. Pincus, D. W., E. M. DiCicco-Bloom, and I. B. Black. 1990. Vasoactive intestinal peptide regulation of neuroblast mitosis and survival: role of cAMP. Brain Res. 514:355-357.

10. Pincus, D. W., E. M. DiCicco-Bloom, and I. B. Black. 1990. Vasoactive intestinal peptide regulates mitosis, differentiation and survival of cultured sympathetic neuroblasts. Nature (Lond.). 343:564-567.

11. Gressens, P., J. M. Hill, I. Gozes, M. Fridkin, and D. E. Brenneman. 1993. Growth factor function of vasoactive intestinal peptide in whole cultured mouse embryos. Nature (Lond.). 362:155-158.

12. Gressens, P., J. M. Hill, B. Paindaveine, I. Gozes, M. Fridkin, and D. E. Brenneman. 1994. Severe microcephaly induced by blockade of vasoactive intestinal peptide function in the primitive neuroepithelium of the mouse. J. Clin. Invest. 94:2020-2027.

13. O'Rahilly, R., and F. Muller. 1987. Developmental Stages in Human Embryos. Carnegie Institute of Washington, Publication No. 637. Carnegie Institute, Washington, DC. $306 \mathrm{pp}$

14. Hill, J. M., D. V. Agoston, P. Gressens, and S. K. McCune. 1994. Distribution of VIP mRNA and two distinct VIP binding sites in the developing rat brain: relation to ontogenic events. J. Comp. Neurol. 342:186-205.

15. Theiler, K. 1989. The House Mouse: Atlas of Embryonic Development. Springer-Verlag New York Inc. New York.

16. Witschi, E. 1962. Development; rat. In Growth Including Reproduction and Morphological Development. P. L. Altman and D. S. Dittmer, editors. Biological Handbooks of the Federation of American Societies for Experimental Biology, Washington, DC. 304-314 pp.

17. Hill, J. M., A. Harris, and D. I. Hilton-Clarke. 1992. Regional distribution of guanine nucleotide-sensitive and guanine nucleotide-insensitive vasoactive intestinal peptide receptors in rat brain. Neuroscience. 48:925-932.

18. Giladi, E., Y. Shani, and I. Gozes. 1990. The complete structure of the rat VIP gene. Mol. Brain Res. 7:261-265.

19. Young, W. S., III, E. Mezey, and R. E. Siegel. 1986. Vasopressin and oxytocin mRNAs in adrenalectomized and Brattleboro rats: analysis by in situ hybridization histochemistry. Mol. Brain Res. 1:231-241.

20. Chomczynski, P., and N. Sacchi. 1987. Single-step method of RNA isolation by acid guanidinium thiocyanate-phenol-chloroform extraction. Anal. Biochem. 162:156-159.

21. Kawaskai, E. S., and A. M. Wang. 1989. Detection of gene expression In PCR Technology: Principles and Applications of DNA Amplifications. F. A. Erlick, editor. Stockton Press Inc. New York. 89-97 pp.

22. Nishizawa, M., Y. Hayakawa, N. Yanaihara, and H. Okamoto. 1985. Nucleotide sequence divergence and functional constraint in VIP precursor mRNA evolution between human and rat. FEBS Lett. 183:55-59.

23. Danielson, P. E., S. Forss-Petter, M. A. Brow, L. Calavetta, J. Douglass, R. J. Milner, and J. G. Sutcliff. 1988. A cDNA clone of the rat mRNA encoding cyclophilin. DNA (NY). 7:261-267.

24. Brenneman, D. E., J. M. Hill, G. W. Glazner, I. Gozes, and T. W. Phillips. 1995. Interleukin-1 alpha and vasoactive intestinal peptide: enigmatic regulation of neuronal survival. Int. J. Dev. Neurosci. 13:187-200.

25. McCune, S. K., M. M. Voigt, and J. M. Hill. 1992. Developmental ex- 
pression of the alpha-1A, alpha-1B and alpha-1C adrenergic receptor subtype mRNAs in the rat brain. Soc. Neurosci. Abst. 18:457.

26. Altman, J., and S. A. Bayer. 1984. The development of the rat spinal cord. Adv. Anat. Embryol. Cell Biol. 85:1-166.

27. Gozes, I., P. Schachter, Y. Shani, and E. Giladi. 1988. Vasoactive intestinal peptide gene expression from embryos to aging rats. Neuroendocrinology. 47:27-31.

28. Tyrrell, S., and S. C. Landis. 1994. The appearance of NPY and VIP in sympathetic neuroblasts and subsequent alterations in their expression. J. Neurosci. 14:4529-4547.

29. Moody, T. W., D. P. Taylor, and C. B. Pert. 1981. Effects of guanine nucleotides on CNS neuropeptide receptors. J. Supramol. Struct. 15:153-159.

30. Fatatis, A., L. A. Holtzclaw, R. Avidor, D. E. Brenneman, and J. T. Russell. 1994. Vasoactive intestinal peptide increases intracellular calcium in astroglia: synergism with alpha-adrenergic receptors. Proc. Natl. Acad. Sci. USA. 91:2036-2040.

31. Olah, Z., C. Lehel, W. B. Anderson, D. E. Brenneman and D. V. Agoston. 1994. Subnanomolar concentration of VIP induces the nuclear translocation of protein kinase $\mathrm{C}$ in neonatal rat cortical astrocytes. J. Neurosci. Res. 39: 355-363.

32. Gozes, I., S. K. McCune, L. Jacobsen, D. Warren, T. W. Moody, M. Fridkin, and D. E. Brenneman. 1991. An antagonist to vasoactive intestinal peptide affects cellular functions in the central nervous system. J. Pharmacol. Exp. Ther. 257:959-966.

33. Ottesen, B., H. Ulrichsen, J. Fahrenkrug, J.-J. Larsen, G. Wagner, L.
Schierup, and F. Sondergaard. 1982. Vasoactive intestinal polypeptide and the female genital tract: relationship to reproductive phase and delivery. Am. $J$. Obstet. Gynecol. 143:414-420.

34. Page, E. W., C. A. Villee, and D. B. Villee. 1981. Human Reproduction, Essentials of Reproductive and Perinatal Medicine. 3rd edition. W. B. Saunders Co., Philadelphia. 526 pp.

35. Obregon, M. J., J. Mallol, R. Pastor, and G. Morreale de Escobar. 1984. L-thyroxine and 3,3',5'-triiodo-L-thyroxine in rat embryos before onset of fetal thyroid function. Endocrinology. 114:305-307.

36. Morreale de Escobart, G., R. Pastor, M. J. Obregon, and F. Escobar del Ray. 1985. Effects of maternal hypothyroidism on the weight and thyroid hormone content of rat embryonic tissues, before and after onset of fetal thyroid function. Endocrinology. 117:1890-1900.

37. Unterman, T. G., T. A. Buchanan, and N. Freinkel. 1989. Access to maternal insulin to the rat conceptus prior to allantoic placentation. Diabetes Res. 10:115-120.

38. Zolti, M., Z. Ben-Rafael, R. Meirom, M. Shemesh, D. Bider, S. Mashaiach, and R. N. Apte. 1991. Cytokine involvement in oocytes and early embryos. Fertil. Steril. 56:265-272.

39. Robertson, S. A., and R. F. Seamark. 1992. Granulocyte-macrophage colony stimulating factor (GM-CSF): one of a family of epithelial cell-derived cytokines in the preimplantation uterus. Reprod. Fertil. Dev. 4:435-448.

40. Medlock, E. S., D. L. Kaplan, M. Cecchini, T. R. Ulich, J. del Castillo, and J. Andresen. 1993. Granulocyte colony-stimulating factor crosses the placenta and stimulates fetal rat granulopoiesis. Blood. 81:916-922. 